\title{
Regime Shifts, Resilience, AND Biodiversity IN Ecosystem Management
}

\author{
Carl Folke, ${ }^{1,2}$ Steve Carpenter, ${ }^{2,3}$ Brian Walker, ${ }^{4}$ \\ Marten Scheffer, ${ }^{5}$ Thomas Elmqvist, ${ }^{1}$ Lance Gunderson, ${ }^{6}$ \\ and C.S. Holling ${ }^{7}$ \\ ${ }^{l}$ Department of Systems Ecology, Stockholm University, SE-106 91 Stockholm, \\ Sweden; email: calle@system.ecology.su.se; thomase@ecology.su.se \\ ${ }^{2}$ Beijer International Institute of Ecological Economics, Royal Swedish Academy \\ of Sciences, Stockholm, Sweden \\ ${ }^{3}$ Center for Limnology, University of Wisconsin, Madison, Wisconsin 53706; \\ email: srcarpen@wisc.edu \\ ${ }^{4}$ Sustainable Ecosystems, CSIRO, Canberra, ACT, 2601, Australia; \\ email:Brian.Walker@csiro.au \\ ${ }^{5}$ Aquatic Ecology and Water Quality Management Group, Wageningen Agricultural \\ University, Wageningen, The Netherlands; email: Marten.Scheffer@wur.nl \\ ${ }^{6}$ Department of Environmental Studies, Emory University, \\ Atlanta, Georgia 30322; email: lgunder@emory.edu \\ ${ }^{7} 16871$ Sturgis Circle, Cedar Key, Florida 32625; email: holling@zoo.ufl.edu
}

Key Words alternate states, regime shifts, response diversity, complex adaptive systems, ecosystem services

- Abstract We review the evidence of regime shifts in terrestrial and aquatic environments in relation to resilience of complex adaptive ecosystems and the functional roles of biological diversity in this context. The evidence reveals that the likelihood of regime shifts may increase when humans reduce resilience by such actions as removing response diversity, removing whole functional groups of species, or removing whole trophic levels; impacting on ecosystems via emissions of waste and pollutants and climate change; and altering the magnitude, frequency, and duration of disturbance regimes. The combined and often synergistic effects of those pressures can make ecosystems more vulnerable to changes that previously could be absorbed. As a consequence, ecosystems may suddenly shift from desired to less desired states in their capacity to generate ecosystem services. Active adaptive management and governance of resilience will be required to sustain desired ecosystem states and transform degraded ecosystems into fundamentally new and more desirable configurations. 


\section{INTRODUCTION}

Humanity strongly influences biogeochemical, hydrological, and ecological processes, from local to global scales. We currently face more variable environments with greater uncertainty about how ecosystems will respond to inevitable increases in levels of human use (Steffen et al. 2004). At the same time, we seem to challenge the capacity of desired ecosystem states to cope with events and disturbances (Jackson et al. 2001, Paine et al. 1998). The combination of these two trends calls for a change from the existing paradigm of command-and-control for stabilized "optimal" production to one based on managing resilience in uncertain environments to secure essential ecosystem services (Holling \& Meffe 1996, Ludwig et al. 2001). The old way of thinking implicitly assumes a stable and infinitely resilient environment, a global steady state. The new perspective recognizes that resilience can be and has been eroded and that the self-repairing capacity of ecosystems should no longer be taken for granted (Folke 2003, Gunderson 2000). The challenge in this new situation is to actively strengthen the capacity of ecosystems to support social and economic development. It implies trying to sustain desirable pathways and ecosystem states in the face of continuous change (Folke et al. 2002, Gunderson \& Holling 2002).

Holling (1973), in his seminal paper, defined ecosystem resilience as the magnitude of disturbance that a system can experience before it shifts into a different state (stability domain) with different controls on structure and function and distinguished ecosystem resilience from engineering resilience. Engineering resilience is a measure of the rate at which a system approaches steady state after a perturbation, that is, the speed of return to equilibrium, which is also measured as the inverse of return time. Holling (1996) pointed out that engineering resilience is a less appropriate measure in ecosystems that have multiple stable states or are driven toward multiple stable states by human activities (Nyström et al. 2000, Scheffer et al. 2001).

Here, we define resilience as the capacity of a system to absorb disturbance and reorganize while undergoing change so as to retain essentially the same function, structure, identity, and feedbacks (Walker et al. 2004). The ability for reorganization and renewal of a desired ecosystem state after disturbance and change will strongly depend on the influences from states and dynamics at scales above and below (Peterson et al. 1998). Such cross-scale aspects of resilience are captured in the notion of a panarchy, a set of dynamic systems nested across scales (Gunderson $\&$ Holling 2002). Hence, resilience reflects the degree to which a complex adaptive system is capable of self-organization (versus lack of organization or organization forced by external factors) and the degree to which the system can build and increase the capacity for learning and adaptation (Carpenter et al. 2001b, Levin 1999).

Several studies have illustrated that ecological systems and the services that they generate can be transformed by human action into less productive or otherwise less desired states. The existence of such regime shifts (or phase shifts) is an area of active research. Regime shifts imply shifts in ecosystem services and 
consequent impacts on human societies. The theoretical basis for regime shifts has been described by Beisner et al. (2003), Carpenter (2003), Ludwig et al. (1997), Scheffer \& Carpenter (2003), and Scheffer et al. (2001).

Here, we review the evidence of regime shifts in terrestrial and aquatic ecosystems in relation to resilience and discuss its implications for the generation of ecosystem services and societal development. Regime shifts in ecosystems are increasingly common as a consequence of human activities that erode resilience, for example, through resource exploitation, pollution, land-use change, possible climatic impact and altered disturbance regimes. We also review the functional role of biological diversity in relation to regime shifts and ecosystem resilience. In particular, we focus on the role of biodiversity in the renewal and reorganization of ecosystems after disturbance-what has been referred to as the back-loop of the adaptive cycle of ecosystem development (Holling 1986). In this context, the insurance value of biodiversity becomes significant. It helps sustain desired states of dynamic ecosystem regimes in the face of uncertainty and surprise (Elmqvist et al. 2003). Strategies for transforming degraded ecosystems into new and improved configurations are also discussed.

\section{REGIME SHIFTS AND DYNAMICS OF RESILIENCE IN ECOSYSTEMS}

Ecosystems are complex, adaptive systems that are characterized by historical dependency, nonlinear dynamics, threshold effects, multiple basins of attraction, and limited predictability (Levin 1999). Increasing evidence suggests that ecosystems often do not respond to gradual change in a smooth way (Gunderson \& Pritchard 2002). Threshold effects with regime shifts from one basin of attraction to another have been documented for a range of ecosystems (see Thresholds Database on the Web site www.resalliance.org). Passing a threshold marks a sudden change in feedbacks in the ecosystem, such that the trajectory of the system changes directiontoward a different attractor. In some cases, crossing the threshold brings about a sudden, sharp, and dramatic change in the responding state variables, for example, the shift from clear to turbid water in lake systems (Carpenter 2003). In other cases, although the dynamics of the system have "flipped" from one attractor to another, the transition in the state variables is more gradual, such as the change from a grassy to a shrub dominated rangeland (Walker \& Meyers 2004). In Table 1, we provide examples of documented shifts between alternate states and expand on some of them in the text.

\section{Temperate Lakes}

Lake phosphorus cycles exhibit multiple regimes, each stabilized by a distinctive set of feedbacks. Generally, two regimes have attracted the most interest, although deeper analyses have revealed even greater dynamic complexities (Carpenter 2003, 
TABLE 1 Documented shifts between states in different kinds of ecosystems

\begin{tabular}{|c|c|c|c|}
\hline Ecosystem type & Alternate state 1 & Alternate state 2 & References \\
\hline \multicolumn{4}{|l|}{ Freshwater systems } \\
\hline \multirow[t]{2}{*}{ Temperate lakes } & Clear water & Turbid eutrophied water & Carpenter 2003 \\
\hline & Game fish abundant & Game fish absent & $\begin{array}{l}\text { Post et al. 2002, Walters \& } \\
\text { Kitchell 2001, Carpenter } 2003\end{array}$ \\
\hline Tropical lakes & Submerged vegetation & Floating plants & Scheffer et al. $2003^{1}$ \\
\hline Shallow lakes & Benthic vegetation & Blue-green algae & $\begin{array}{l}\text { Blindow et al. 1993, Scheffer } \\
\text { et al. 1993, Scheffer 1997, } \\
\text { Jackson } 2003\end{array}$ \\
\hline \multirow[t]{2}{*}{ Wetlands } & Sawgrass communities & Cattail communities & Davis 1989, Gunderson 2001 \\
\hline & Salt marsh vegetation & Saline soils & Srivastava \& Jefferies 1995 \\
\hline \multicolumn{4}{|l|}{ Marine systems } \\
\hline \multirow[t]{2}{*}{ Coral reefs } & Hard coral dominance & Macroalgae dominance & $\begin{array}{l}\text { Knowlton 1992, Done 1992, } \\
\text { Hughes 1994, McCook } 1999\end{array}$ \\
\hline & Hard coral dominance & Sea urchin barren & Glynn 1988, Eakin 1996 \\
\hline \multirow[t]{2}{*}{ Kelp forests } & Kelp dominance & Sea urchin dominance & Steneck et al. 2002, Konar \& Estes 2003 \\
\hline & Sea urchin dominance & Crab dominance & Steneck et al. 2002 \\
\hline Shallow lagoons & Seagrass beds & Phytoplankton blooms & Gunderson 2001, Newman et al. 1998 \\
\hline Coastal seas & Submerged vegetation & Filamentous algae & Jansson \& Jansson 2002, Worm et al. 1999 \\
\hline Benthic foodwebs & Rock lobster predation & Whelk predation & Barkai \& McQuaid 1988 \\
\hline Ocean foodwebs & Fish stock abundant & Fish stock depleted & $\begin{array}{l}\text { Steele 1998, Walters \& Kitchell 2001, } \\
\text { de Roos \& Persson } 2002\end{array}$ \\
\hline
\end{tabular}


Forest systems

Temperate forests

Tropical forests

Savanna and grassland

Grassland

Savanna

Arctic, sub-Arctic systems

Steppe/tundra
Spruce-fir dominance

Pine dominance

Hardwood-hemlock

Birch-spruce succession

Rain forest

Woodland

Native crab consumers

Perennial grasses

Native vegetation

Tall shrub, perennial grasses

Grass dominated

Grass dominated

Tundra
Aspen-birch dominance

Hardwood dominance

Aspen-birch

Pine dominance

Grassland

Grassland

Invasive ants

Desert

Invasive species

Low shrub, bare soil

Shrub dominated

Moss dominated

Boreal forest
Holling 1978

Peterson 2002

Frelich \& Reich 1999

Danell et al. 2003

Trenbath et al. 1989

Dublin et al. 1990

O'Dowd et al. 2003

Wang \& Eltahir 2000, Foley et al. 2003 van de Koppel et al. 1997

Vitousek et al. 1987

Bisigato \& Bertiller 1997

Anderies et al. 2003, Brown et al. 1997

Zimov et al. 1995

Bonan et al. 1992, Higgins et al. 2002 
Scheffer 1997). The two regimes of most concern to people who use the lakes are the clear-water and turbid-water regimes. In the clear-water regime, phosphorus inputs, phytoplankton biomass, and recycling of phosphorus from sediments are relatively low. In the turbid-water regime, these same variables are relatively high. The turbid-water regime provides lower ecosystem services because of abundant toxic cyanobacteria, anoxic events, and fish kills (Smith 1998).

In the clear-water regime of shallow lakes (lakes that do not stratify thermally), extensive beds of higher aquatic plants (macrophytes) stabilize sediments and reduce recycling of phosphorus to phytoplankton (Jeppesen et al. 1998, Scheffer 1997). Macrophyte beds may be lost because of shading by phytoplankton when high phosphorus inputs stimulate phytoplankton growth. Bottom-feeding (benthivorous) fishes that increase in abundance with nutrient enrichment damage the macrophytes and cause turbidity by resuspending sediment. Once the macrophytes are lost, sediments are more easily resuspended by waves, and rapid recycling of phosphorus from sediments maintains the turbid regime. Reversion to the clearwater state requires reduction of phosphorus inputs, but even if phosphorus inputs are reduced, the turbid state may remain resilient. With sufficiently low levels of phosphorus the ecosystem can possibly be perturbed to the clear-water state by temporarily removing fish, which allows macrophytes to recover, stabilizes the sediments, and reduces phosphorus cycling, thereby consolidating the clear-water state.

A different mechanism operates in deep (thermally stratified) lakes, although the clear-water and turbid-water states are similar (Carpenter 2003). Interactions of iron with oxygen are the key (Caraco et al. 1991, Nürnberg 1995). In the clear-water regime, rates of phytoplankton production, sedimentation, and oxygen consumption in deep water are low. Consequently the deep water remains oxygenated most of the time, and iron remains in the oxidized state, which binds phosphorus in insoluble forms. When phosphorus inputs are high, rates of phytoplankton production, sedimentation, and oxygen consumption increase. The deep water is anoxic part if not all of the time, iron is in the reduced state, and phosphorus dissolves into the water. Recycling of phosphorus from sediments makes the turbid-water state resilient. The regime can be shifted back to clear water by extreme reductions of phosphorus input or by various manipulations that decrease recycling of phosphorus (Carpenter et al. 1999, Cooke et al. 1993).

Similar mechanisms may have operated during massive oceanic events in the remote past. Episodes of large-scale phosphorus release in the oceans may represent a regime shift in which high phytoplankton production forms a strong positive feedback with phosphorus recycling from deep waters or sediments (Algeo \& Scheckler 1998, Van Capellen \& Ingall 1994).

\section{Tropical Lakes}

Experiments, field data, and models suggest that a situation with extensive freefloating plant cover and a state characterized by submerged plants tend to be alternate regimes (Scheffer et al. 2003). Dense mats of floating plants have an adverse effect on freshwater ecosystems because they create anoxic conditions, 
which strongly reduce animal biomass and diversity. Floating plants are superior competitors for light and carbon. Submerged plants are better competitors for nutrients and may prevent expansion of free-floating plants through a reduction of available nutrients in the water column. As a result, over a range of conditions, the lake can exist in either a floating-plant-dominated state or a submerged-plantdominated state. Both states are resilient, but nutrient enrichment reduces the resilience of the submerged plant state. A single drastic harvest of floating plants can induce a permanent shift to an alternate state dominated by rooted submerged growth forms if the nutrient loading is not too high (Scheffer et al. 2003).

\section{Wetlands, Estuaries, and Coastal Seas}

In the Everglades, the freshwater marshes have shifted from wetlands dominated by sawgrass to cattail marshes because of nutrient enrichment. The soil phosphorous content defines the alternate states, and several types of disturbances (fires, drought, or freezes) can trigger a switch between these states (Gunderson 2001).

In Florida Bay, the system has flipped from a clear-water, seagrass-dominated state to one of murky water, algae blooms, and recurrently stirred-up sediments. Hypotheses that have been proposed to explain this shift include change in hurricane frequency, reduced freshwater flow entering the Bay, higher nutrient concentrations, removal of large grazers such as sea turtles and manatees, sea-level rise, and construction activities that restrict circulation in the Bay (Gunderson 2001).

The Baltic Sea is eutrophied and overfished (Elmgren 2001), and a shift has occurred in the coastal subsystem from submerged vegetation dominated by perennial fucoids to filamentous and foliose annual algae with lower levels of diversity (Kautsky et al. 1986). Jansson \& Jansson (2002) propose that these conditions represent alternate states. Grazers on turf algae, such as gastropods, contribute to the maintenance of the fucoid-dominated state, but nutrient influx overrides grazing control and shifts the system into a less desired state (Worm et al. 1999). In addition to shading by filamentous algae (Berger et al. 2003), increased sedimentation caused by excessive phytoplankton production hinders recruitment and settlement of fucoids plants (Eriksson \& Johansson 2003), which may lock the coastal subsystem into the undesired state.

\section{Coral Reefs}

The current shift of coral reefs into dominance by fleshy algae was long preceded by diminishing stocks of fishes and increased nutrient and sediment runoff from land (Jackson et al. 2001). The grazing of algae by fish species and other grazers contributes to the resilience of the hard-coral-dominated reef by, for example, keeping the substrate open for recolonization of coral larvae after disturbances such as hurricanes (Nyström et al. 2000).

In the Caribbean, overfishing of herbivores (dominated by fishes on reefs) led to expansion of sea urchin populations as the key grazers on invading algae. Thereby, the coral-dominated state was maintained, albeit at low resilience. 
The high densities of the sea urchin populations may have contributed to their eventual demise when a disease outbreak spread throughout the Caribbean and reduced their numbers by two orders of magnitude, which precipitated the shift to the algal-dominated state that persists today (Hughes 1994, Knowlton 1992).

In other areas, high densities of grazing echinoids erode the reef matrix and, if unchecked, have the capacity to destroy reefs, as documented in the Galapagos Islands and elsewhere in the East Pacific (Eakin 1996, Glynn 1988). Loss of macrofauna, reduced fish stocks, replacement of herbivorous fishes by a single species of echinoid, overgrazing by food-limited sea urchins, high levels of erosion by echinoids, and reduced coral recruitment make coral reefs vulnerable to change and subject to regime shifts (Bellwood et al. 2004, Done 1992, Hughes et al. 2003). A significant ecological restructuring of reefs towards "weedy" generalist species of low trophic levels that are adapted to variable environments is underway (Knowlton 2001, McClanahan 2002). Bellwood et al. (2004) describe six different reefs transitions towards less desired states as a consequence of human-induced erosion of resilience (Figure 1).

\section{Kelp Forests}

Remarkably sharp boundaries are found between kelp forests and neighboring "deforested" areas (Konar \& Estes 2003). Also, remarkable switches have occurred

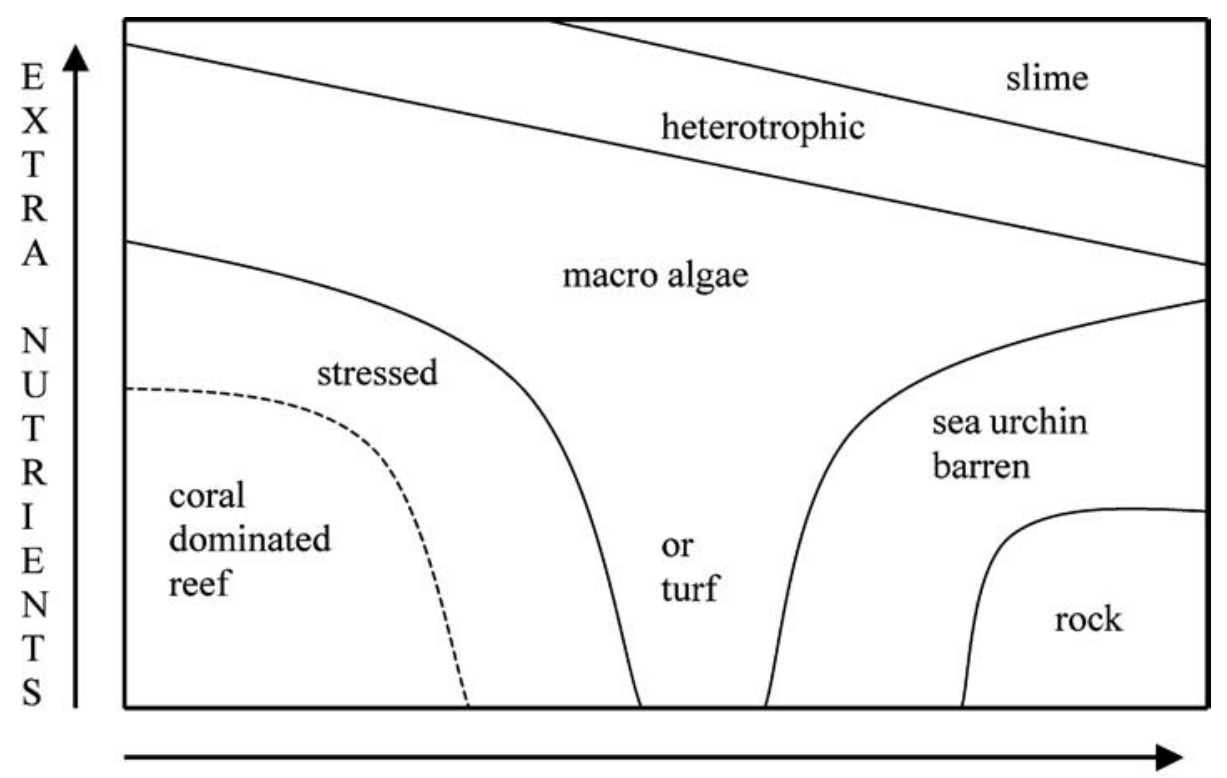

F I S H I N G

Figure 1 Effects of eutrophication and fishing and observed shifts between states in coral reefs (modified from Bellwood et al. 2004). 
between kelp dominance and sea-urchin dominance over time (Steneck et al. 2002). Experiments reveal that sea urchins can control kelp growth in the open areas, but the sweeping of kelp foliage over the rocks in the border region prevents migration of sea urchins into the kelp stands. Thus, kelp stands can withstand herbivory by combining their flexible morphology with the energy of wave-generated surge (Konar \& Estes 2003). Kelp forests can recover if the numbers of sea urchins are reduced by an external factor. Proposed mechanisms include increased predation by sea otters, cycles of diseases, and introduction of sea urchin fishery. The fishing down of coastal food webs has in some locations led to the return of kelp forests devoid of vertebrate apex predators. Large predatory crabs have filled this void in areas of the western North Atlantic (Steneck et al. 2002).

\section{Pelagic Marine Fisheries}

Pelagic marine fish stocks sometimes exhibit sharp changes consistent with regime shifts (Steele 1996, 1998). Large changes in fish stocks have occurred ever since the introduction of fisheries (Jackson et al. 2001). Similar rapid and massive changes have occurred in freshwater ecosystems subject to sport fishing (Post et al. 2002). Cascading changes are often related to size-structured predation (de Roos \& Persson 2002). Larger individuals of one species eat smaller individuals of other species. If larger individuals of one species become rare for some reason, that species' recruitment can be eliminated by predation from the other species and perhaps lead to severe decline of the population of the first species. Walters \& Kitchell (2001) call this dynamic "cultivation/depensation." If adults of the former species are abundant, they create favorable conditions for their own offspring by reducing the abundance of the latter species. If adults of the former species are overfished, expansion of latter species may permanently prevent reestablishment of the former species.

\section{Savannas}

Marked fluctuations in grass and woody plant biomass are a characteristic feature of savannas, because of their highly variable rainfall, and primary productivity varies up to tenfold from one year to the next (Kelly \& Walker 1976). Herbivores cannot respond fast enough to track these fluctuations, and the accumulation of grass during wet periods means periodic accumulation of fuel and, therefore, fires. The net effect of fires has been to maintain savanna rangelands in more open, grassy states than would be achieved without fires (Scholes \& Walker 1993).

The interaction of fire, herbivory, and variable rainfall has resulted in a grassshrub-livestock system that exhibits regime shifts between an open, grassy state and a dense, woody state, particularly where humans have altered the pattern and intensity of grazing (Anderies et al. 2002). Establishment of shrub seedlings occurs in wet periods when the seedlings can get their roots below the grass-rooting zone to survive the first dry season. A vigorous grass layer for the first few years strongly suppresses established seedlings, but once established, grasses have little effect on 
woody plant growth. Fire has little effect on grasses because it occurs at the end of the dry season when grasses are dormant, but it has a severe effect on woody plants by killing many and reducing others to ground level.

The change from a grassy to a woody state comes about through a combination of sustained grazing pressure and lack of fire. Periods of drought with high stock numbers bring about the death of perennial grasses and lead to reduced grass cover. When followed by good rains this reduced grass cover, in turn, leads to a profusion of woody seedlings. If, at this point, all livestock were removed, enough grass growth would still occur to enable an effective fire and keep the system in a grassy state. However, if grazing pressure is sustained a point is reached in the increasing woody:grass biomass ratio after which, even if all livestock are removed, the competitive effect of the woody plants is such that it prevents the build up of sufficient grass fuel to sustain a fire. The system then stays in the woody state until the shrubs or trees reach full size and, through competition among them, begin to die. The vegetation then opens up for the reintroduction of grass and fire. This process can take 30 or 40 years.

The flip in the rangeland occurs when the resilience of the grassy state has been exceeded - that is, when the amount of change in the ratio of grass:woody vegetation needed to push the system into the woody state falls within the range of the annual fluctuations of this ratio (because of fluctuations in rainfall and grazing pressure). Once this situation is reached, the conditions needed to flip the system (e.g., a period of low rainfall) will inevitably follow.

\section{Forests}

The boreal forests of North America experience distinctive outbreaks of the spruce budworm, with 30 to 45 years and occasionally 60 to 100 years between outbreaks. This defoliating insect destroys large areas of mature softwood forests, principally spruce and fir. Once the softwood forest is mature enough to provide adequate food and habitat for the budworm, and if a period of warm dry weather occurs, budworm numbers can increase sufficiently to exceed the predation rate and trigger an outbreak. A local outbreak can spread over thousands of square kilometers and eventually collapse after 7 to 16 years. Programs of spraying insecticide to control spruce budworm outbreaks exacerbated the conditions for outbreaks over even more extensive areas (Holling 1978). After a defoliation event, aspen and birch often dominate the regenerating forest, but over a period of 20 to 40 years, selective browsing by moose can shift this forest back to a state dominated by conifers (Ludwig et al. 1978).

Browsing that causes change in dominance between tree species that have different effects on ecosystem functions can lead to dramatic effects in forest ecosystems. For example, the gradual reduction of willows by ungulates on the Alaskan floodplain makes room for nitrogen-fixing alders that increase soil fertility and cause overall vegetation change. In the mountain range of Scandinavia, birches dominate young stands, followed by Norway spruce in the forest succession. If 
the birches are heavily browsed by ungulates, spruce does not get shelter and fails. Instead, pines may establish and become dominant, which causes long-term changes in soil fertility (Danell et al. 2003). Forestry and hunting policies affect and shape those trajectories.

Shifts in forest cover, associated with management of fire regimes, in the welldrained soils of the southeastern United States reflect alternate states (Peterson 2002). A pine-dominated savanna, with grasses, palms, or shrubs in the understory, historically covered the region and was the result of frequent ground fires. Hardwood shrubs would invade during fire-free periods but their dominance was inhibited by frequent burning. Because of fire suppression and fragmentation of the landscape, fire frequency decreased and led to either mixed pine-hardwood forests or hardwood forests. Once a canopy of hardwoods is established, the site becomes less flammable and precludes pine regeneration (Peterson 2002).

\section{Regime Shifts and Irreversibility}

In some cases, regime shifts may be largely irreversible. Loss of trees in cloud forests is one example. In some areas, the forests were established under a wetter rainfall regime thousands of years previously. Necessary moisture is supplied through condensation of water from clouds intercepted by the canopy. If the trees are cut, this water input stops and the resulting conditions can be too dry for recovery of the forest (Wilson \& Agnew 1992).

A continental-scale example of an irreversible shift seems to have occurred in Australia, where overhunting and use of fire by humans some 30,000 to 40,000 years ago removed large marsupial herbivores. Without large herbivores to prevent fire and fragment vegetation, an ecosystem of fire and fire-dominated plants expanded and irreversibly switched the ecosystem from a more productive state, dependent on rapid nutrient cycling, to a less productive state, with slower nutrient cycling (Flannery 1994). Similarly, extinction of megafauna at the end of the Pleistocene in Siberia, possibly through improvement in hunting technology, may have triggered an irreversible shift from steppe grassland to tundra. The resulting increase in mosses led to cooler soils, less decomposition, and greater carbon sequestration in peat (Zimov et al. 1995).

\section{VULNERABILITY THROUGH HUMAN-INDUCED LOSS OF RESILIENCE}

As illustrated by the foregoing examples, undesired shifts between ecosystem states are caused by the combination of the magnitudes of external forces and the internal resilience of the system. As resilience declines, the ecosystem becomes vulnerable, and progressively smaller external events can cause shifts. Human actions have increased the likelihood of undesired regime shifts. In Figure 2, we summarize shifts into less desired states as a consequence of human-induced loss of resilience. 


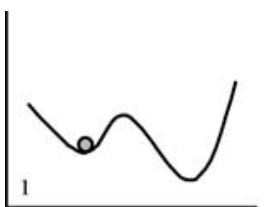

clear-water

lakes

coral-dominated

reefs

grassland

grassland

kelp forests

pine forest

seagrass beds

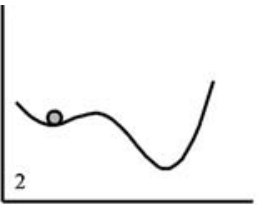

phosphorous accumulation in agricultural soil and lake mud

overfishing, coastal eutrophication

fire prevention

hunting of herbivores

functional elimination of apex predators

microclimate and soil changes, loss of pine regeneration

removal of grazers, lack of hurricanes, salinity moderation, spatial homogenization

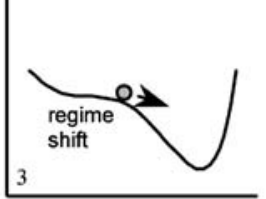

flooding, warming, overexploitation of predators

\section{disease, bleaching} hurricane

good rains, continuous heavy grazing

disease

thermal event, storm, disease,

decreased fire frequency, increased fire intensity

thermal event

phytoplankton blooms

floating-plant dominance

\section{algae-dominated} reefs

shrub-bushland

woodland

sea urchin

dominance

oak forest

\section{nutrient release}

with water table rise during dry spells

Figure 2 Alternate states in a diversity of ecosystems $(1,4)$ and the causes $(2)$ and triggers (3) behind loss of resilience and regime shifts. For more examples, see Thresholds Database on the Web site www.resalliance.org.

Humans have, over historical time but with increased intensity after the industrial revolution, reduced the capacity of ecosystems to cope with change through a combination of top-down (e.g., overexploitation of top predators) and bottom-up impacts (e.g., excess nutrient influx), as well as through alterations of disturbance regimes including climatic change (e.g., prevention of fire in grasslands and forest or increased bleaching of coral reefs because of global warming) (Nyström et al. 2000, Paine et al. 1998, Worm et al. 2002). The result of those combined impacts tends to be leaking, simplified, and "weedy" ecosystems characterized by unpredictability and surprise in their capacity to generate ecosystem services.

The likelihood that an ecological system will remain within a desired state is related to slowly changing variables that determine the boundaries beyond which disturbances may push the system into another state (Scheffer \& Carpenter 2003). 
Consequently, efforts to reduce the risk of undesired shifts between ecosystem states should address the gradual changes that affect resilience rather than focus all effort into trying to control disturbance and fluctuations. The slowly changing variables include such things as land use, nutrient stocks, soil properties, freshwater dynamics, and biomass of long-lived organisms (Gunderson \& Pritchard 2002). In the following sections we focus on biological diversity as a slowly changing variable and its significance in ecosystem resilience.

\section{Trophic Cascades}

Loss of top predators can increase the vulnerability of aquatic ecosystems to eutrophication by excessive nutrient input (Carpenter 2003). In manipulations of whole-lake ecosystems, removal of top predators allows primary producers to respond much more strongly to experimental inputs of nutrients (Carpenter et al. 2001a). The mechanism is a trophic cascade - in the absence of top predators, planktivorous fishes become abundant, and grazing zooplankton are suppressed. When nutrients are added, phytoplankton grow unconstrained by grazers.

Over human history, removal of top predators from nearshore marine ecosystems through fishing may have increased the vulnerability of the ecosystems to coastal nutrient inputs and paved the way for impacts such as eutrophication, algal blooms, disease outbreaks, and species introductions in coastal areas (Jackson et al. 2001). In the Black Sea, for example, overfishing and eutrophication changed the ecosystem from one dominated by piscivorous fishes (bluefish, bonito) and dolphins to one dominated by jellyfish, small-bodied planktivorous fishes, and phytoplankton (Daskalov 2002, Zaitsev \& Mamaev 1997). In the Baltic Sea, removal of top predators such as seals (through pollution and hunting), fishing pressure, and influx of excessive nutrients have caused widespread eutrophication and oxygen deficiency in deeper waters that have wiped out important food chains over nearly $100,000 \mathrm{~km}^{2}$ of sea bottom (Elmgren 1989).

Trophic cascades occur in a diversity of ecosystem, and examples are known from terrestrial systems (Pace et al. 1999). Trophic cascades are becoming another signature of the vast and growing human footprint (Terborgh et al. 2001). Cascading provides nonlinear and often surprising changes in ecosystem dynamics and may lead to regime shifts (Diaz \& Cabido 2001). Trophic cascades seem to be less likely under conditions of high diversity or extensive omnivory in food webs (Pace et al. 1999).

\section{BIODIVERSITY AND RESILIENCE DYNAMICS}

The diversity of functional groups in a dynamic ecosystem undergoing change, the diversity within species and populations, and the diversity of species in functional groups appear to be critical for resilience and the generation of ecosystem services (Chapin et al. 1997, Luck et al. 2003). Two aspects of diversity are distinguished: functional-group diversity and functional-response diversity. 


\section{Functional-Group Diversity}

Functional groups of species in a system refers to groups of organisms that pollinate, graze, predate, fix nitrogen, spread seeds, decompose, generate soils, modify water flows, open up patches for reorganization, and contribute to the colonization of such patches. The persistence of functional groups contributes to the performance of ecosystems and the services that they generate. Loss of a major functional group, such as apex predators, other consumers, or benthic filter-feeders, may, as previously discussed, cause drastic alterations in ecosystem functioning (Chapin et al. 1997, Duffy 2002, Jackson et al. 2001).

However, in systems that lack a specific functional group, the addition of just one species may dramatically change the structure and functioning of ecosystems (Chapin et al. 2000). In Hawaii, the introduced nitrogen-fixing tree Myrica faya has dramatically changed the structure and function in ecosystems where no native nitrogen-fixing species had been present. Once established, M. faya can increase nitrogen inputs up to five times, thereby facilitating establishment of other exotic species (Vitousek et al. 1987). Studies of coastal environments and reefs suggest that more diverse ecosystems are less sensitive to invasion of exotic species (Knowlton 2001, Stachowicz et al. 1999).

\section{Functional-Response Diversity}

Recently, Naeem \& Wright (2003) argued that functional-response traits should be considered and distinguished from functional-effect traits when analyzing biodiversity effects on ecosystem functioning. Variability in responses of species within functional groups to environmental change is critical to ecosystem resilience (Chapin et al. 1997, Norberg et al. 2001). Elmqvist et al. (2003) call this property response diversity, and it is defined as the diversity of responses to environmental change among species that contribute to the same ecosystem function. For example, in lake systems, animal plankton species with higher tolerance to low $\mathrm{pH}$ sustain the grazing function on phytoplankton during acid conditions (Frost et al. 1995). In semiarid rangelands, resilience of production to grazing pressure is achieved by maintaining a high number of apparently less important and less common, or apparently "redundant," species from the perspective of those who want to maximize production, each with different capacities to respond to different combinations of rainfall and grazing pressures. The species replace each other over time, which ensures maintenance of rangeland function over a range of environmental conditions (Walker et al. 1999).

The role of genetic and population diversity for response diversity is illustrated through sockeye salmon production in the rivers and lakes of Bristol Bay, Alaska. Several hundred discrete spawning populations display diverse life-history characteristics and local adaptations to the variation in spawning and rearing habitats. Geographic regions and life-history strategies that were minor producers during a certain climatic regime have been the major producers during other climatic regimes, which allowed the aggregate of the populations to sustain its 
productivity in fluctuating freshwater and marine environments. The response diversity of the fish stocks has been critical in sustaining their resilience to environmental change. Such management is in stark contrast to the common focus on only the most productive runs at a certain moment in time (Hilborn et al. 2003).

Springer et al. (2003) propose that the decimation of the great whales since the World War II caused their foremost natural predator, killer whales, to begin feeding more intensively on seals, sea lions, and sea otters, which are the major predators on sea urchins, thereby possibly contributing to shifts from kelp-dominated to seaurchin-dominated coastal areas. In areas where sea-urchin predator diversity is low (e.g., in western North Atlantic and Alaska), the transition between kelp dominance and sea-urchin dominance has been rapid, frequent, widespread, and often long lasting. In southern California, where the diversity of predators, herbivores, and kelps is high, deforestation events have been rare or patchy in space and short in duration, and no single dominant sea-urchin predator exists (Steneck et al. 2002). Functional redundancy and response diversity may contribute to the resilience of kelp forests in California.

An important distinction should be made between real redundancy and apparent redundancy, which involves response diversity within functional groups. Functional redundancy refers to the number of species that perform the same function. Adding more species does not lead to increased system performance where there is real functional redundancy. Furthermore, if this set of functionally redundant species does not exhibit any response diversity, they do not contribute to the insurance value.

We argue that the biodiversity insurance metaphor needs to be revived with a focus on how to sustain ecosystem resilience and the services it generates in the context of multiple-equilibrium systems and human-dominated environments (Folke et al. 1996). Ecosystems with high response diversity increase the likelihood for renewal and reorganization into a desired state after disturbance (Chapin et al. 1997, Elmqvist et al. 2003).

\section{Biodiversity in Ecosystem Renewal and Reorganization}

Recovery after disturbance has often been measured as return time to the equilibrium state. Frequently, the sources of ecosystem recovery have been taken for granted and the phases of ecosystem development that prepare the system for succession and recovery largely neglected. Disturbance releases the climax state and is followed by renewal and reorganization. We refer to those phases as the back-loop of ecosystem development (Gunderson \& Holling 2002). Functional roles in the back-loop and sources of resilience are critical for sustaining an ecosystem within a desired state in the face of change (Nyström \& Folke 2001).

In coral reef systems, three functional groups of herbivores, dominated by fishes, play different and complementary roles in renewing and reorganizing reefs into a coral-dominated state after disturbance. These groups-grazers, scrapers, and bioeroders-prepare the reef for recovery. Bioeroding fishes remove dead corals 
and other protrusions, which exposes the hard reef matrix for new settlement of coralline algae and corals. Grazers remove seaweed, which reduces coral overgrowth and shading by macroalgae. Scrapers remove algae and sediment by close cropping, which facilitates settlement, growth, and survival of coralline algae and corals. Without bioeroders, recovery may be inhibited by extensive stands of dead staghorn and tabular coral that can remain intact for years before collapsing and taking with them attached coral recruits. Without grazers, algae can proliferate and limit coral settlement and survival of juvenile and adult colonies. Without scrapers, sediment-trapping algal turfs develop that smother coral spat and delay or prevent recovery. The extents to which reefs possess these functional groups are central to their capacity to renew and reorganize into a coral-dominated state in the face of disturbance (Bellwood et al. 2004).

The biological sources of renewal and reorganization for ecosystem resilience consist of functional groups of biological legacies and mobile link species and their support areas in the larger landscape or seascape. For example, large trees serve as biological legacies after fire and storms in forest ecosystems (Elmqvist et al. 2001, Franklin \& MacMahon 2000), and seed banks and vegetative propagules play the same role in tundra ecosystems (Vavrek et al. 1999). Mobile link species connect habitats, sometimes widely separated in space and time (Lundberg \& Moberg 2003). For example, vertebrates that eat fruit, such as flying foxes, play a key functional role in the regeneration of tropical forests hit by disturbances such as hurricanes and fire by bringing in seeds from surrounding ecosystems that result in renewal and reorganization (Cox et al. 1991, Elmqvist et al. 2001). The functional group of grazers on coral reefs connect a wide range of spatial scales from centimeters, such as amphipods and sea urchins, to thousands of kilometers, such as green turtles (Elmqvist et al. 2003). By operating at different spatial and temporal scales, competition among species within the guild of grazers is minimized, and the robustness over a wider range of environmental conditions is enhanced (Peterson et al. 1998). Such response diversity plays a significant role in the capacity of ecosystems to renew and reorganize into desired states after disturbance.

Metapopulation analyses have largely focused on dispersal, connectivity, recovery, and life history of species, populations, and communities. Great potential lies in redirecting this knowledge into addressing the role of functional groups and response diversity in ecosystem resilience that considers the central role of human actors in this context.

A number of observations suggest that biodiversity at larger spatial scales (i.e., landscapes and regions) ensures that appropriate key species for ecosystem functioning are recruited to local systems after disturbance or when environmental conditions change (Bengtsson et al. 2003, Nyström \& Folke 2001, Peterson et al. 1998). The current emphasis on setting aside "hot spot" areas of diversity and protecting species richness in reserves will in itself not be a viable option in human-dominated environments (Folke et al. 1996). Present static reserves should be complemented with dynamic reserves, such as ecological fallows and dynamic successional reserves (Bengtsson et al. 2003), and serve as one important tool 
that contributes to sustaining the configuration of functional groups and response diversity required for renewing and reorganizing desired ecosystem states after disturbance. In this sense, biological diversity provides insurance, flexibility, and risk spreading across scales in dynamic landscapes and seascapes.

Hence, spatial and temporal relations of functional groups that renew and help reorganize ecosystem development after disturbance, and their response diversity, will influence the ability of ecosystems to remain within desired states.

\section{MANAGING RESILIENCE FOR DEVELOPMENT}

Archaeological research indicates that over time human societies have degraded the capacity of ecosystems to sustain societal development (Redman 1999, van der Leeuw 2000). Historical overfishing of coastal waters has created simplified, leaky, and weedy ecosystems that rapidly respond to external influences in an unpredictable fashion (Jackson et al. 2001). A shifting baseline, an incremental lowering of environmental standards over time (Pauly 1995), may occur, and each new human generation may adapt to the new conditions of less diverse and less productive ecosystems.

Our review clearly illustrates that regime shifts in ecosystems are, to a large extent, driven by human actions. A combination of top-down impacts, such as fishing down food webs and losing response diversity and functional groups of species, and bottom-up impacts, such as accumulation of nutrients, soil erosion, or redirection of water flows, as well as altered disturbance regimes, such as suppression of fire and increased frequency and intensity of storms, have shifted several ecosystems into less desired states with diminished capacities to generate ecosystem services.

Shifts from desired to less desired states may often follow gradual loss of ecosystem resilience. Resilience has multiple attributes, but four aspects are critical (Walker et al. 2004):

1. Latitude is the maximum amount the system can be changed before losing its ability to reorganize within the same state; basically it is the width of the stability domain or the basin of attraction.

2. Resistance is the ease or difficulty of changing the system; deep basins of attraction indicate that greater disturbances are required to change the current state of the system away from the attractor.

3. Precariousness is how close the current trajectory of the system is to a threshold that, if breached, makes reorganization difficult or impossible.

4. Cross-scale relations (i.e., panarchy) is how the above three attributes are influenced by the states and dynamics of the (sub)systems at scales above and below the scale of interest.

Ecosystem management of resilience, biodiversity, and regime shifts needs to address those attributes. Such an initiative will require adaptability among the 
actors involved in ecosystem management (Berkes et al. 2003). Adaptability is the capacity of actors in a system to manage resilience in the face of uncertainty and surprise (Gunderson \& Holling 2002). Humans are a part of, and not apart from, the trajectory and stability domain of the system and will, to a large extent, determine their own paths through management of the ecosystem. Human actors can $(a)$ move thresholds away from or closer to the current state of the system by altering latitude, (b) move the current state of the system away from or closer to the threshold by altering precariousness, or $(c)$ make the threshold more difficult or easier to reach by altering resistance. Actors can also manage cross-scale interactions to avoid or instigate loss of resilience at larger and more catastrophic scales (Holling et al. 1998).

Human actions have often altered slowly changing ecological variables, such as soils or biodiversity, with disastrous social consequences that did not appear until long after the ecosystems were first affected. A current major problem in this context is the large-scale salinization of land and rivers in Australia. About 5.7 million hectares are currently at risk for dryland salinity, and the amount of land at risk could rise to over 17 million hectares by 2050. Extensive land clearing during the past 200 years has removed native woody vegetation to make way for agricultural crops and pasture grasses that transpire much less water. Thus, more water is infiltrating the soils and causing groundwater tables to rise. The rising water mobilizes salts and causes problems with salinity both in rivers and in the soils, which severely reduces the capacity for plant growth (Gordon et al. 2003). Increased vulnerability, as a consequence of loss of resilience, places a region on a trajectory of greater risk of the panoply of stresses and shocks that occur over time (Kasperson et al. 1995).

Most semiarid ecosystems have suffered from severe overexploitation by excessive grazing and agriculture that resulted in depletion of vegetation biomass and soil erosion. These changes are often difficult to reverse because of positive feedbacks that stabilize the new situation. According to one hypothesis, rainy periods associated with El Niño can be used in combination with grazer control to restore degraded ecosystems (Holmgren \& Scheffer 2001). Removing grazers to regenerate vegetation during normal years will not be sufficient, because conditions are too dry. Also, wet years do not allow regeneration if grazers remain present. However, removing grazers during a wet year pulse may tip the balance and allow reorganization into a more desired state, and this pulse management may be sufficient for the state to remain intact, subject to grazing. Clearly, responding to El Niño as an opportunity for shifting an ecosystem back to the desired state demands a highly responsive social system, organized for rapid and flexible adaptation (Berkes et al. 2003).

At times, human societies or groups may find themselves trapped in an undesired basin of attraction that is becoming so wide and so deep that movement to a new basin, or sufficient reconfiguration of the existing basin, becomes extremely difficult. A major challenge in ecosystem management is to develop social and ecological capacity to transform such an undesired basin into a fundamentally new and more desirable configuration, a new stability landscape defined by different 
state variables or old state variables supplemented by new ones. We call this challenge transformability, that is, the capacity to create untried beginnings from which to evolve a fundamentally new way of living when existing ecological, economic, and social conditions make the existing system untenable (Walker et al. 2004). The new way of living requires social-ecological resilience to cope with future change and unpredictable events (Olsson et al. 2004).

Resilience-building management needs to be flexible and open to learning. It attends to slowly changing, fundamental variables such as experience, memory, and diversity in both social and ecological systems (Folke et al. 2003). The crucial slow variables that determine the underlying dynamic properties of the system and that govern the supply of essential ecosystem services need to be identified and assessed. The processes and drivers that determine the dynamics of this set of crucial variables need to be identified and assessed. The role of biological diversity in ecosystem functioning and response to change should be explicitly accounted for in this context and acknowledged in resilience-building policies.

\section{CONCLUSIONS}

Ecosystems can be subject to sharp regime shifts. Such shifts may more easily occur if resilience has been reduced as a consequence of human actions. Human actions may cause loss of resilience through the following methods:

- removal of functional groups of species and their response diversity, such as the loss of whole trophic levels (top-down effects),

- impact on ecosystems via emissions of waste and pollutants (bottom-up effects) and climate change, and

- alteration of the magnitude, frequency, and duration of disturbance regimes to which the biota is adapted.

Loss of resilience through the combined and often synergistic effects of those pressures can make ecosystems more vulnerable to changes that previously could be absorbed. As a consequence, they may suddenly shift from desired to less desired states in their capacity to sustain ecosystem services to society. In some cases, these shifts may be irreversible (or too costly to reverse). Irreversibility is a reflection of changes in variables with long turnover times (e.g., biogeochemical, hydrological, or climatic) and loss of biological sources and interactions for renewal and reorganization into desired states.

In light of these changes and their implication for human well-being, the capacities for self-repair of ecosystems can no longer be taken for granted. Active adaptive management and governance of resilience will be required to help sustain or create desired states of ecosystems. A first step in this direction is to understand better the interactions between regime shifts, biological diversity, and ecosystem resilience. 


\section{ACKNOWLEDGMENTS}

This work is a product of the Resilience Alliance and has been supported by a grant from the JS McDonnell Foundation. In addition, the work of Carl Folke and Thomas Elmqvist is partly funded by grants from the Swedish Research Council for the Environment, Agricultural Sciences and Spatial Planning (Formas). The Beijer Institute has supported the collaboration with the review article.

\section{The Annual Review of Ecology, Evolution, and Systematics is online at http://ecolsys.annualreviews.org}

\section{LITERATURE CITED}

Algeo TJ, Scheckler SE. 1998. Terrestrialmarine teleconnections in the Devonian: Links between the evolution of land plants, weathering processes, and marine anoxic events. Philos. Trans. R. Soc. London Ser. B 353:113-28

Anderies JM, Janssen MA, Walker BH. 2002. Grazing management, resilience, and the dynamics of a fire-driven rangeland system. Ecosystems 5:23-44

Barkai A, McQuaid C. 1988. Predator-prey role reversal in a marine benthic ecosystem. Science 242:62-64

Beisner BE, Haydon DT, Cuddington K. 2003. Alternative stable states in ecology. Front. Ecol. Environ. 1:376-82

Bellwood DR, Hughes TP, Folke C, Nyström M. 2004. Confronting the coral reef crisis. Nature 429:827-33

Bengtsson J, Angelstam P, Elmqvist T, Emanuelsson U, Folke C, et al. 2003. Reserves, resilience, and dynamic landscapes. Ambio 32:389-96

Berger R, Henriksson E, Kautsky L, Malm T. 2003. Effects of filamentous algae and deposited matter on the survival of Fucus vesiculosus $L$. germlings in the Baltic Sea. Aquat. Ecol. 37:1-11

Berkes F, Colding J, Folke C, eds. 2003. Navigating Social-Ecological Systems: Building Resilience for Complexity and Change. Cambridge: Cambridge Univ. Press

Bisigato AJ, Bertiller MB. 1997. Grazing effects on patchy dryland vegetation in North- ern Patagonia. J. Arid Environ. 36:63953

Blindow I, Anderson G, Hargeby A, Johansson S. 1993. Long-term pattern of alternative stable states in two shallow eutrophic lakes. Freshw. Biol. 30:159-67

Bonan GB, Pollard D, Thompson SL. 1992. Effects of boreal forest vegetation on global climate. Nature 359:716-18

Brown JH, Valone TJ, Curtin CG. 1997. Reorganization of an arid ecosystem in response to recent climate change. Proc. Natl. Acad. Sci. USA 94:9729-33

Caraco NF, Cole JJ, Likens GE. 1991. A crosssystem study of phosphorus release from lake sediments. In Comparative Analysis of Ecosystems, ed. J Cole, G Lovett, S Findlay, pp. 241-58. New York: Springer-Verlag

Carpenter SR. 2003. Regime Shifts in Lake Ecosystems: Pattern and Variation. Excellence in Ecology Series 15. Oldendorf/Luhe, Germany: Ecol. Inst.

Carpenter SR, Cole JJ, Hodgson JR, Kitchell JF, Pace ML, et al. 2001a. Trophic cascades, nutrients, and lake productivity: whole-lake experiments. Ecol. Monogr. 71:163-86

Carpenter SR, Ludwig D, Brock WA. 1999. Management of eutrophication for lakes subject to potentially irreversible change. Ecol. Appl. 9:751-71

Carpenter SR, Walker B, Anderies JM, Abel N. 2001b. From metaphor to measurement: Resilience of what to what? Ecosystems 4:76581 
Chapin FS, Walker BH, Hobbs RJ, Hooper DU, Lawton JH, et al. 1997. Biotic control over the functioning of ecosystems. Science 277:500-4

Chapin FS, Zavaleta ES, Eviner VT, Naylor RL, Vitousek PM, et al. 2000. Consequences of changing biodiversity. Nature 405:234-42

Cooke GD, Welch EB, Peterson SA, Newroth PR. 1993. Restoration and Management of Lakes and Reservoirs. Boca Raton, FL: Lewis

Cox PA, Elmqvist T, Rainey EE, Pierson ED. 1991. Flying foxes as strong interactors in South Pacific Island ecosystems: a conservation hypothesis. Conserv. Biol. 5:448-54

Danell K, Bergström R, Edenius L, Ericsson G. 2003. Ungulates as drivers of tree population dynamics at module and genet levels. Forest Ecol. Manag. 181:67-76

Daskalov GM. 2002. Overfishing drives a trophic cascade in the Black Sea. Mar. Ecol. Prog. Ser. 225:53-63

Davis SM. 1989. Sawgrass and cattail production in relation to nutrient supply in the Everglades. In Fresh Water Wetlands \& Wildlife, 9th Annual Symposium, Savannah River Ecology Laboratory, 24-27 March 1986, ed. RR Sharitz, JW Gibbons, pp. 32542. Charleston, SC: US Dep. Energy

de Roos A, Persson L. 2002. Size-dependent life history traits promote catastrophic collapses of top predators. Proc. Natl. Acad. Sci. USA 99:12907-12

Diaz S, Cabido M. 2001. Vive la difference: plant functional diversity matters to ecosystem processes. Trends Ecol. Evol. 16:64655

Done TJ. 1992. Phase shifts in coral reef communities and their ecological significance. Hydrobiologia 247:121-32

Dublin HT, Sinclair ARE, McGlade J. 1990. Elephants and fire as causes of multiple stable states in the Serengeti-Mara woodlands. J. Anim. Ecol. 59:1147-64

Duffy JE. 2002. Biodiversity and ecosystem function: the consumer connection. Oikos 99:201-19

Eakin CM. 1996. Where have all the carbon- ates gone? A model comparison of calcium carbonate budgets before and after the 19821983 El Nino at Uva Island in the eastern Pacific. Coral Reefs 15:109-19

Elmgren R. 1989. Man's impact on the ecosystems of the Baltic Sea: energy flows today and at the turn of the century. Ambio 18:32632

Elmgren R. 2001. Understanding human impact on the Baltic ecosystem: changing views in recent decades. Ambio 30:222-31

Elmqvist T, Folke C, Nyström M, Peterson G, Bengtsson J, et al. 2003. Response diversity and ecosystem resilience. Front. Ecol. Environ. 1:488-94

Elmqvist T, Wall M, Berggren AL, Blix L, Fritioff S, Rinman U. 2001. Tropical forest reorganization after cyclone and fire disturbance in Samoa: remnant trees as biological legacies. Conserv. Ecol. 5:10. http://www.consecol.org/vol5/iss2/art10

Eriksson BK, Johansson G. 2003. Sedimentation reduces recruitment success of $\mathrm{Fu}$ cus vesiculosus (Phaeophyceae) in the Baltic Sea. Eur. J. Phycol. 38:217-22

Flannery T. 1994. The Future Eaters: An Ecological History of the Australasian Lands and People. Sydney: Reed New Holland

Foley JA, Coe MT, Scheffer M, Wang G. 2003. Regime shifts in the Sahara and Sahel: interactions between ecological and climatic systems in Northern Africa. Ecosystems 6:52439

Folke C. 2003. Freshwater and resilience: a shift in perspective. Philos. Trans. R. Soc. London Ser. B 358:2027-36

Folke C, Carpenter SR, Elmqvist T, Gunderson L, Holling CS, Walker B. 2002. Resilience and sustainable development: building adaptive capacity in a world of transformations. Ambio 31:437-40

Folke C, Colding J, Berkes F. 2003. Synthesis: building resilience and adaptive capacity in social-ecological systems. See Berkes et al. 2003, pp. 352-87

Folke C, Holling CS, Perrings C. 1996. Biological diversity, ecosystems and the human scale. Ecol. Appl. 6:1018-24 
Franklin JF, MacMahon JA. 2000. Enhanced: messages from a mountain. Science 288:1183-90

Frelich LE, Reich PB. 1999. Neighborhood effects, disturbance severity and community stability in forests. Ecosystems 2:151-66

Frost TM, Carpenter SR, Ives AR, Kratz TK. 1995. Species compensation and complementarity in ecosystem function. In Linking Species and Ecosystems, ed. CG Jones, JH Lawton, pp. 224-39. New York: Chapman and Hall

Glynn PW. 1988. El Nino warming, coral mortality and reef framework destruction by echinoid bioerosion in the eastern Pacific. Galaxea 7:129-60

Gordon L, Dunlop M, Foran B. 2003. Land cover change and water vapour flows: learning from Australia. Philos. Trans. R. Soc. London Ser. B 358:1973-84

Gunderson LH. 2000. Ecological resilience: in theory and application. Annu. Rev. Ecol. Syst. 31:425-39

Gunderson LH. 2001. Managing surprising ecosystems in southern Florida. Ecol. Econ. 37:371-78

Gunderson LH, Holling CS, eds. 2002. Panarchy: Understanding Transformations in $\mathrm{Hu}$ man and Natural Systems. Washington, DC: Island Press

Gunderson LH, Pritchard L, eds. 2002. Resilience and the Behavior of Large-Scale Ecosystems. Washington, DC: Island Press

Higgins PAT, Mastrandrea MD, Schneider SH. 2002. Dynamics of climate and ecosystem coupling: abrupt changes and multiple equilibria. Philos. Trans. R. Soc. London Ser. B 357:647-55

Hilborn R, Quinn TP, Schindler DE, Rogers DE. 2003. Biocomplexity and fisheries sustainability. Proc. Natl. Acad. Sci. USA 100:656468

Holling CS. 1973. Resilience and stability of ecological systems. Annu. Rev. Ecol. Syst. 4:1-23

Holling CS. 1978. The spruce-budworm/forestmanagement problem. In Adaptive Environmental Assessment and Management. Inter- national Series on Applied Systems Analysis, ed. CS Holling, 3:143-82. New York: John Wiley \& Sons

Holling CS. 1986. The resilience of terrestrial ecosystems: local surprise and global change. In Sustainable Development of the Biosphere, ed. WC Clark, RE Munn, pp. 292317. Cambridge: Cambridge Univ. Press

Holling CS. 1996. Engineering resilience versus ecological resilience. In Engineering within Ecological Constraints, ed. PC Schulze, pp. 31-44. Washington, DC: Natl. Acad. Press

Holling CS, Berkes F, Folke C. 1998. Science, sustainability, and resource management. In Linking Social and Ecological Systems: Management Practices and Social Mechanisms for Building Resilience, ed. $\mathrm{F}$ Berkes, C Folke, pp. 342-62. Cambridge: Cambridge Univ. Press

Holling CS, Meffe GK. 1996. Command and control and the pathology of natural resource management. Conserv. Biol. 10:32837

Holmgren M, Scheffer M. 2001. El Niño as a window of opportunity for the restoration of degraded arid ecosystems. Ecosystems 4:151-59

Hughes TP. 1994. Catastrophes, phase shifts, and large-scale degradation of a Caribbean coral reef. Science 265:1547-51

Hughes TP, Baird AH, Bellwood DR, Card M, Connolly SR, et al. 2003. Climate change, human impacts, and the resilience of coral reefs. Science 301:929-33

Jackson JBC, Kirb MX, Berher WH, Bjorndal KA, Botsford LW, et al. 2001. Historical overfishing and the recent collapse of coastal ecosystems. Science 293:629-38

Jackson LJ. 2003. Macrophyte-dominated and turbid states of shallow lakes: evidence from Alberta lakes. Ecosystems 6:213-23

Jansson B-O, Jansson AM. 2002. The Baltic Sea: Reversibly unstable or irreversibly stable? See Gunderson \& Pritchard 2002, pp. 71-109

Jeppesen E, Sondergaard M, Sondergaard M, Christofferson K, eds. 1998. The Structuring 
Role of Submerged Macrophytes in Lakes. Berlin: Springer-Verlag

Kautsky N, Kautsky H, Kautsky U, Waern M. 1986. Decreased depth penetration of $\mathrm{Fu}$ cus vesiculosus (L.) since the 1940s indicates eutrophication of the Baltic Sea. Mar. Ecol. Prog. Ser. 28:1-8

Kasperson JX, Kasperson RE, Turner BL. 1995. Regions at Risk: Comparisons of Threatened Environments. New York: United Nations University Press

Kelly RD, Walker BH. 1976. The effects of different forms of land use on the ecology of a semi-arid region in south-eastern Rhodesia. J. Ecol. 64:553-76

Knowlton N. 1992. Thresholds and multiple stable states in coral reef community dynamics. Am. Zool. 32:674-82

Knowlton N. 2001. The future of coral reefs. Proc. Natl. Acad. Sci. USA 98:5419-25

Konar B, Estes JA. 2003. The stability of boundary regions between kelp beds and deforested areas. Ecology 84:174-85

Levin S. 1999. Fragile Dominion: Complexity and the Commons. Reading, MA: Perseus Books

Luck GW, Daily GC, Ehrlich PR. 2003. Population diversity and ecosystem services. Trends Ecol. Evol. 18:331-36

Ludwig D, Jones DD, Holling CS. 1978. Qualitative analysis of insect outbreak systems: Spruce-budworm and forest. J. Anim. Ecol. 47:315-32

Ludwig D, Mangel M, Haddad B. 2001. Ecology, conservation, and public policy. Annu. Rev. Ecol. Syst. 32:481-517

Ludwig D, Walker B, Holling CS. 1997. Sustainability, stability, and resilience. Conserv. Ecol. 1:7. http://www.consecol.org/vol1/iss1/ art7

Lundberg J, Moberg F. 2003. Mobile link organisms and ecosystem functioning: implications for ecosystem resilience and management. Ecosystems 6:87-98

McClanahan TR. 2002. The near future of coral reefs. Environ. Conserv. 29:460-83

McCook LJ. 1999. Macroalgae, nutrients and phase shifts on coral reefs: scientific issues and management consequences for the Great Barrier Reef. Coral Reefs 18:357-67

Naeem S, Wright JP. 2003. Disentangling biodiversity effects on ecosystem functioning: deriving solutions to a seemingly insurmountable problem. Ecol. Lett. 6:567-79

Newman S, Schuette J, Grace JB, Rutchey K, Fontaine T, et al. 1998. Factors influencing cattail abundance in the northern Everglades. Aquat. Bot. 60:265-80

Norberg J, Swaney DP, Dushoff J, et al. 2001. Phenotypic diversity and ecosystem functioning in changing environments: a theoretical framework. Proc. Natl. Acad. Sci. USA 98:11376-81

Nürnberg GK. 1995. Quantifying anoxia in lakes. Limnol. Oceanogr. 40:1100-11

Nyström M, Folke C. 2001. Spatial resilience of coral reefs. Ecosystems 4:406-17

Nyström M, Folke C, Moberg F. 2000. Coralreef disturbance and resilience in a humandominated environment. Trends Ecol. Evol. 15:413-17

O'Dowd DJ, Green PT, Lake PS. 2003. Invasional 'meltdown' on an oceanic island. Ecol. Lett. 6:812-17

Olsson P, Folke C, Hahn T. 2004. Socialecological transformation for ecosystem management: the development of adaptive co-management of a wetland landscape in southern Sweden. Ecol. Soc. 9(4):2. http:// www.ecologyandsociety.org/vol9/iss4/art2

Pace ML, Cole JJ, Carpenter SR, Kitchell JF. 1999. Trophic cascades revealed in diverse ecosystems. Trends Ecol. Evol. 14:483-88

Paine RT, Tegner MJ, Johnson EA. 1998. Compounded perturbations yield ecological surprises. Ecosystems 1:535-45

Pauly D. 1995. Anecdotes and the shifting baseline syndrome of fisheries. Trends Ecol. Evol. 10:430

Peterson GD, Allen CR, Holling CS. 1998. Ecological resilience, biodiversity, and scale. Ecosystems 1:6-18

Peterson GD. 2002. Forest dynamics in the Southeastern United States: managing multiple stable states. See Gunderson \& Pritchard 2002, pp. 227-46 
Post JR, Sullivan M, Cox S, Lester NP, Walters CJ, et al. 2002. Canada's recreational fisheries: the invisible collapse? Fisheries 27:6-17

Redman CL. 1999. Human Impact on Ancient Environments. Tucson, AZ: Univ. Arizona Press

Scheffer M. 1997. The Ecology of Shallow Lakes. London: Chapman and Hall

Scheffer M, Carpenter SR. 2003. Catastrophic regime shifts in ecosystems: linking theory to observation. Trends Ecol. Evol. 18:648-56

Scheffer M, Carpenter SR, Foley J, Folke C, Walker BH. 2001. Catastrophic shifts in ecosystems. Nature 413:591-96

Scheffer M, Hosper SH, Meijer ML, Moss B, Jeppesen E. 1993. Alternative equilibria in shallow lakes. Trends Ecol. Evol. 8:27579

Scheffer M, Szabo S, Gragnani A, van Nes EH, Rinaldi S, et al. 2003. Floating plant dominance as a stable state. Proc. Natl. Acad. Sci. USA 100:4040-45

Scholes RJ, Walker BH. 1993. Nylsuley: The Study of an African Savanna. Cambridge: Cambridge Univ. Press

Smith VH. 1998. Cultural eutrophication of inland, estuarine and coastal waters. In Successes, Limitations and Frontiers of Ecosystem Science, eds. ML Pace, PM Groffman, pp. 7-49. New York: Springer-Verlag

Springer AM, Estes JA, van Vliet GB, Williams TM, Doak DF, et al. 2003. Sequential megafaunal collapse in the North Pacific Ocean: an ongoing legacy of industrial whaling? Proc. Natl. Acad. Sci. USA 100:1222328

Srivastava DS, Jefferies RL. 1995. Mosaics of vegetation and soil salinity: a consequence of goose foraging in an arctic salt marsh. Can. J. Bot. 73:75-83

Stachowicz JJ, Whitlach RB, Osman RW. 1999. Species diversity and invasion resistance in marine ecosystems. Science 286:1577-79

Steele JH. 1998. Regime shifts in marine ecosystems. Ecol. Appl. 8:S33-S36

Steele JH. 1996. Regime shifts in fisheries management. Fish. Res. 25:19-23
Steffen W, Sanderson A, Jäger J, Tyson PD, Moore B III, et al. 2004. Global Change and the Earth System: A Planet Under Pressure. Heidelberg: Springer-Verlag. 336 pp.

Steneck RS, Graham MH, Bourque BJ, Corbett D, Erlandson JM, et al. 2002. Kelp forest ecosystems: biodiversity, stability, resilience and future. Environ. Conserv. 29:436-59

Terborgh J, Lopez L, Nunez P, Rao M, Shahabuddin G, et al. 2001. Ecological meltdown in predator-free forest fragments. Science 294:1923-26

Trenbath BR, Conway GR, Craig IA. 1989. Threats to sustainability in intensified agricultural systems: analysis and implications for management. In Agroecology: Researching the Ecological Basis for Sustainable Agriculture, ed. SR Gliessman, pp. 337-65. Berlin: Springer-Verlag

Van Cappellen P, Ingall ED. 1994. Benthic phosphorus regeneration, net primary production, and ocean anoxia: a model of the coupled marine biogeochemical cycles of carbon and phosphorus. Paleoceanography 9:677-92

van de Koppel J, Rietkerk M, Weissing FJ. 1997. Catastrophic vegetation shifts and soil degradation in terrestrial grazing systems. Trends Ecol. Evol. 12:352-56

van der Leeuw S. 2000. Land degradation as a socionatural process. In The Way the Wind Blows: Climate, History, and Human Action, eds. RJ McIntosh, JA Tainter, SK McIntosh, pp. 357-83, New York: Columbia Univ. Press Vavrek MC, Fetcher N, McGraw JB, Shaver GR, Chapin FS, Bovard B. 1999. Recovery of productivity and species diversity in Tussock tundra following disturbance. Arct. Antarct. Alp. Res. 31:254-58

Vitousek PM, Walker LR, Whiteaker LD, Muellerdombois D, Matson PA. 1987. Biological invasion by Myrica-Faya alters ecosystem development in Hawaii. Science 238:802-4

Walker BH, Holling CS, Carpenter SR, Kinzig AS. 2004. Resilience, adaptability and transformability. Ecol. Soc. In press

Walker BH, Kinzig A, Langridge J. 1999. Plant 
attribute diversity, resilience, and ecosystem function: the nature and significance of dominant and minor species. Ecosystems 2: 95-113

Walker BH, Meyers JA. 2004. Thresholds in ecological and social-ecological systems: a developing database. Ecol. Soc. 9(2):3

Walters CJ, Kitchell JF. 2001. Cultivation/depensation effects on juvenile survival and recruitment: implications for the theory of fishing. Can. J. Fish. Aquat. Sci. 58:1-12

Wang GL, Eltahir EAB. 2000. Role of vegetation dynamics in enhancing the lowfrequency variability of the Sahel rainfall. Water Resour. Res. 36:1013-21

Wilson JB, Agnew ADQ. 1992. Positivefeedback switches in plant communities $A d v$. Ecol. Res. 23:263-336
Worm B, Lotze H, Boström C, Engkvist R, Labanauskas V, Sommer U. 1999. Marine diversity shift linked to interactions among grazers, nutrients and propagule banks. Mar. Ecol. Prog. Ser. 185:309-14

Worm B, Lotze H, Hillebrand H, Sommer U. 2002. Consumer versus resource control of species diversity and ecosystem functioning. Nature 417:848-51

Zaitsev Y, Mamaev V. 1997. Marine Biological Diversity in the Black Sea: A Study of Change and Decline. New York: United Nations Publications

Zimov SA, Chuprynin VI, Oreshko AP, Chapin FS, Reynolds JF, Chapin MC. 1995. Steppetundra transition: a herbivore-driven biome shift at the end of the Pleistocene. Am. Nat. 146:765-94 
Copyright of Annual Review of Ecology, Evolution, \& Systematics is the property of Annual Reviews Inc. and its content may not be copied or emailed to multiple sites or posted to a listserv without the copyright holder's express written permission. However, users may print, download, or email articles for individual use. 
Copyright of Annual Review of Ecology, Evolution, \& Systematics is the property of Annual Reviews Inc. and its content may not be copied or emailed to multiple sites or posted to a listserv without the copyright holder's express written permission. However, users may print, download, or email articles for individual use. 